\title{
Harta Bersama Menurut Hukum Islam dan Perundang-undangan di Indonesia*
}

\author{
(TREASURE HOUSEHOLDS ACCORDING TO ISLAMIC LAW \\ AND POSITIVE LAW IN INDONESIA)
}

\author{
Kholil Nawawi \\ Fakultas Agama Islam UIKA Bogor \\ Jl. KH. Sholeh Iskandar \\ E-mail: nawawi12@yahoo.com
}

\begin{abstract}
Every marriage has brought wealth and acquired prior to the marriage of each spouse party. Average property together in marriage or the so-called property prices along Gono gini is generated through syirkah or cooperation between husband and wife. The scholars have different opinions about this, but the majority say as shirkah Abdan. When divorce occurs, then do the division of property together with an agreed manner.
\end{abstract}

Keywords: Assets Together, Islamic Law, Positive Law

\begin{abstract}
Abstrak: Setiap perkawinan mempunyai harta yang dibawa dan diperoleh sebelum melakukan perkawinan dari masing-masing pihak suami atau istri. Sedang harta bersama dalam perkawinan atau disebut harta gono gini merupakan harga bersama yang dihasilkan melalui syirkah atau kerja sama antara suami dan istri. Para ulama berbeda pendapat akan hal ini, akan tetapi mayoritas mengatakannya sebagai syirkah abdan. Bila perceraian terjadi, maka dapat dilakukan pembagian harta bersama dengan mengkiyaskannya dengan syirkah abdan atau dengan cara lain yang disepakati.
\end{abstract}

Kata Kunci: Harta Bersama, Hukum Islam, Hukum Positif

* Diterima tanggal naskah diterima: 11 Maret 2013, direvisi: 20 April 2013, disetujui untuk terbit: 21 Mei 2013. 


\section{Pendahuluan}

Pasal 38 Undang-Undang Nomor 1 Tahun 1974 tentang Perkawinan menyebutkan setidaknya ada tiga penyebab putusnya perkawinan yaitu; karena kematian, karena perceraian atau talak, dan atas putusan Pengadilan. Kematian salah seorang dari suami-istri secara otomatis menyebabkan putusnya perkawinan. Adapun putusnya perkawinan karena perceraian dapat terjadi melalui talak atau berdasarkan gugatan cerai dari istri yang dikabulkan oleh Pengadilan Agama. Perkawinan juga dapat terputus karena putusan Pengadilan atas permohonan salah satu pihak dimana pihak lainnya hilang tidak tentu rimbanya berturut-turut dan berlangsung selama paling kurang 2 tahun (pasal 39 Undang-undang perkawinan No.1 Thaun 1974, jo. Pasal 28 PMA Nomor 3 Tahun 1975, jo. Pasal 16 dan 19 Peraturan Pemerintah No.9 Tahun 1975).

Disamping itu ada beberapa penyebab lain putusnya perkawinan menurut Hakim Islam yaitu: khulu', zhihar, ila', li'an, dan murtad. Akibat hukum yang muncul karena putusnya hubungan perkawinan disebabkan talak atau perceraian adalah:

1. Mut'ah (pemberian suami untuk menggembirakan hati mantan istrinya karena telah ditalak) baik berupa uang maupun benda.

2. Tentang masa Iddah atau masa tunggu untuk istri.

3. Tentang nafkah dan pemeliharaan anak (hadhanah).

4. Tentang harta bersama atau harta gono-gini.

Salah satu akibat hukum yang ditimbulkan oleh perceraian adalah tentang pembagian harta bersama, karena sebagaimana diketahui bahwa setiap perkawinan masing-masing pihak dari suami atau istri mempunyai harta yang dibawa dan diperoleh sebelum mereka melakukan perkawinan. Suami-istri yang telah melakukan perkawinan juga mempunyai harta yang diperoleh selama perkawinan yang kemudian dalam Undang-Undang Perkawinan No. 1 Tahun 1974 disebut dengan harta bersama.

Suami maupun istri mempunyai hak untuk mempergunakan harta bersama yang telah diperolehnya tersebut, selagi untuk kepentingan rumah tangganya tentunya dengan persetujuan kedua belah pihak. Dan ini berbeda dengan harta bawaan yang keduanya mempunyai hak untuk mempergunakannya tanpa harus ada persetujuan dari keduanya atau masing- 
masing berhak menguasainya sepanjang para pihak tidak menentukan lain, sebagaimana yang diatur dalam UU Perkawinan No. 1 Tahun 1974 pasal 35.

Bila terjadi perceraian, maka mengenai harta bersama diselesaikan menurut Hukum Islam bagi suami istri yang beragama Islam dan menurut Kitab Undang-undang Hukum Perdata bagi suami istri non-Islam. ${ }^{1}$

\section{Pengertian Harta Bersama}

Dari segi bahasa harta artinya adalah, "Barang-barang (uang dsb) yang menjadi kekayaan." 2 Sedangkan menurut istilah sesuatu yang dapat dikuasai da diambil manfaatnya secara lazim. Yang dimaksud harta bersama yaitu "Harta yang dipergunakan (dimanfaatkan) bersama-sama", ${ }^{3}$ atau "Harta Gono Gini". ${ }^{4}$

Pencaharian bersama suami istri atau yang kemudian disebut harta bersama atau harta gono gini ialah harta kekayaan yang dihasilkan bersama oleh suami istri selama mereka diikat oleh tali perkawinan, hal itu termuat dalam pasal 35 UU Perkawinan No.1 Tahun 1974. Sebenarnya istilah harta bersama berasal dari hukum adat yang pada pokoknya sama diseluruh wilayah Indonesia. "Dikebanyakan daerah harta yang terdapat selama perkawinan menjadi harta bersama."

Penyebutan harta bersama suami istri tidak sama antara satu daerah dengan daerah lainnya sebagai contoh, "Di Minangkabau harta bersama dinamakan Harta-Suarang," di Kalimantan disebut barang perpantangan, di Sulawesi Selatan (Makasar dan Bugis) cakkara, di Jawa Tengah dan Timur barang gono gini, di Jawa Barat guna-kaya atau campur-kaya."6

Tidak hanya dalam penyebutan harta bersama yang berbeda antara satu daerah dengan daerah yang lainnya namun juga mengenai tata cara

\footnotetext{
${ }^{1}$ Mohd. Idris Ramulyo, Perkawinan Islam suatu Analisis dari undang-undang No.1 Tahun 1974 dan Kompilasi Hukum Islam, Jakarta: Bumi Aksara, 1996.

2 Departemen Pendidikan dan Kebudayaan, Kamus Besar Bahasa Indonesia, Jakarta: Balai Pustaka, 1991

${ }^{3}$ Ibid

${ }^{4}$ Ensiklopedia Hukum Islam, Jakarta: PT ichtiar Baru van Hoeve, 2001

${ }^{5}$ R. Van Dijk, Pengantar Hukum Adat Indonesia, terj. A. Soehardi, Jakarta: Penerbit Sumur Bandung, 1960

${ }^{6}$ R. Wirjono Prodjodikoro, Hukum Perkawinan di Indonesia, Jakarta: Sumur Bandung, 1960
} 
pembagiannya, meski demikian secara garis besar dalam hukum adat pembagian harta bersama adalah masing-masing suami atau istri mendapatkan sebagian dari harta bersama. Beberapa daerah di Jawa Tengah memiliki kebiasaan pembagian harta bersama yaitu suami mendapatkan dua pertiga dan istri mendapat sepertiga. Azas pembagian tersebut di Jawa Tengah disebut azas "sakgendong-sakpikul". Tata cara pembagian seperti ini juga dikenal di pulau Bali berdasarkan azas "susuhun-sarembat". Begitu juga di kepulauan Bagai, terdapat azas dua-pertiga dan sepertiga tersebut. Akan tetapi dalam perkembangannya, azas "sakgendong-sakpikul" atau "susuhun-sarembat" dalam pembagian harta bersama makin lama makin lenyap. ${ }^{7}$

Berawal dari hukum adat inilah kemudian permasalahan harta bersama di adopsi pemerintah menjadi hukum positif sebagai upaya unifikasi hukum untuk mengatasi konflik yang mungkin muncul di tengah masyarakat.

\section{Harta Bersama Menurut Hukum Islam}

Konsep harta dalam rumah tangga Islam menurut Alquran adalah:

a. Harta adalah tonggak kehidupan rumah tangga, sebagaimana firman Allah SWT dalam Al-Qur'an surat An-nisa ayat:5

“Dan janganlah kamu serahkan kepada orang-orang yang belum sempurna akalnya, harta (mereka yang ada dalam kekuasaan-Nya) yang dijadikan Allah sebagai pokok kehidupan. Berilah mereka belanja dan pakaian (dari hasil harta itu) dan ucapkanlah pada mereka kata-kata baik". (Surat An-nisa: 32) ${ }^{8}$

Kewajiban suami berkenaan dengan harta,

1. Memberikan mahar kepada istri, Qs An-Nisa ayat 4

"Berikanlah maskawin (mahar) kepada wanita (yang kamu nikahi) sebagai pemberian dengan penuh kerelaan. Kemudian jika mereka menyerahkan kepada kamu sebagian dari maskawin itu dengan senang hati, maka makanlah (ambilah) pemberian itu (sebagai makanan) yang sedap lagi baik akibatnya" (surat An-Nisa: 4) ${ }^{9}$

\footnotetext{
${ }^{7}$ Muhammad Isna Wahyudi, "Harta Bersama: Antara Konsepsi dan Tuntutan Keadilan".

${ }^{8}$ Departemen Agama Republik Indonesia, Al-Qur'an dan Terjemah, Bandung: PT Syamil Cipta Media, 2005

${ }^{9}$ Ibid
} 
2. Memberikan nafkah kepada istri dan anak, Qs Al-Baqarah 233

"Dan kewajiban ayah memberi makan dan pakaian (nafkah) kepada para ibu dengan cara ma'ruf." (surat Al-Baqarah: 233)10

\section{b. Jika terjadi perceraian suami istri maka:}

1) Istri mendapatkan seluruh mahar jika istri telah melakukan hubungan seks dengan suaminya atau salah satu dari suami istri meninggal dunia dan mahar telah ditentukan, Allah berfirman dalam Al-Qur'an surat An-Nisa ayat 20-21:

"Dan jika kamu ingin mengganti istrimu dengan istri yang lain, sedang kamu telah memberikan kepada seseorang di antara mereka harta yang banyak, maka janganlah kamu mengambil kembali dari padanya barang sedikitpun. Apakah kamu akan mengambilnya kembali dengan jalan tuduhan yang dusta dan dengan (menanggung) doa yang nyata? Bagaimana kamu akan mengambilnya kembali, padahal sebagian kamu telah bergaul (bercampur) dengan yang lain sebagai suami-istri. Dan mereka (istri-istrimu) telah mengambil dari kamu perjanjian yang kuat.(surat an-Nisa:20-21) ${ }^{11}$

2) Istri mendapat separuh mahar jika ia belum melakukan hubungan seks dengan suaminya dan mahar telah ditentukan. Allah berfirman dalam surat al-Baqarah ayat 237:

"Jika kamu menceraikan istri-istrimu sebelum kamu bercampur dengan mereka, padahal sesungguhnya kamu sudah menentukan maharnya, maka bayarlah seperdua dari mahar yang telah kamu tentukan itu.(surat al-Baqarah:237) ${ }^{12}$

3) Istri memperoleh mut'ah jika ia belum melakukan hubungan seks dengan suaminya dan mahar belum ditentukan, Qs Al-Baqarah 236:

"Tidak ada kewajiban membayar (mahar) atas kamu, jika kamu menceraikan istri-istri kamu sebelum kamu bercampur dengan mereka dan sebelum kamu menentukan maharnya. Dan hendaklah kamu berikan suatu mut'ah (pemberian) kepada mereka. Orang yang mampu menurut kemampuannya dan orang yang miskin menurut kemampuannya dan orang yang miskin menurut kemampuannya (pula), yaitu pemberian

\footnotetext{
10 Ibid

11 Ibid

12 Ibid
} 
menurut yang patut. Yang demikian itu merupakan ketentuan bagi orang-orang yang berbuat kebajikan." (surat al-Baqarah: 236) ${ }^{13}$

Penyebutan istilah harta bersama dalam keluarga atau gono-gini secara inplisit memang tidak dijumpai dalam al-Qur'an atau al-Hadits karena istilah ini berasal dari hukum adat ('uruf) pada masyarakat yang mengenal pencampuran harta kekayaan dalam keluarga salah satunya adalah masyarakat Indonesia. Untuk menggali hukumnya, maka harta bersama dianalogikan kepada syirkah, seperti yang telah di uraikan sebelumnya bahwa harta bersama adalah harta kekayaan yang di hasilkan bersama oleh pasangan suami istri selama mereka terikat dengan tali perkawinan. Atau dengan kata lain harta yang dihasilkan oleh perkongsian (syirkah) antara suami dan istri.

Ismail Muhammad Syah dalam disertasinya (1984:282) telah mengembangkan suatu pendapat, Pencaharian suami istri mestinya termasuk dalam Rubu' Mu'amalah lebih lanjut dikatakan, oleh karena itu masalah pencaharian bersama suami istri termasuk perkongsian atau syarikat. ${ }^{14}$

Persekutuan (sirkah) adalah pencampuran. Para ahli fiqih mendefinisikannya sebagai akad dua orang yang bersekutu dalam modal dan keuntungan. ${ }^{15}$ Dasar hukum disyariatkannya syirkah adalah Alquran AlSunah dan Ijma'. Dalam Alquran Allah Swt berfirman:

“...maka mereka bersekutu dalam yang sepertiga itu..." (Surat An_Nisa:12)16

“...Dan sesungguhnya kebanyakan dari orang-orang yang berserikat itu sebahagian mereka berbuat zalimmepadasebahagian yang lain, kecuali orang orang yang beriman dan mengerjakan amal yang salah; dan amat sedikitlah mereka ini..."(Surat Shad:24) ${ }^{17}$

Dalam As-Sunah Rasulullah SAW bersabda:

Sesungguhnya Allah SWT berfirman: 'Aku adalah yang ketiga dari dua orang yang bersekutu selama salah satu dari keduanya tidak mengkhiantai

\section{Ibid}

14 M.Yahya Harahap,"Informasi Materi Kompilasi Hukum Islam: mempositifkan abstraksi hukum islam" dalam Cik Hasan Bisri, Ed; Kompilasi hukum islam dan peradilan agama dalam sistem hukum nasional, Jakarta: logos wacana ilmu, 1999

15 Sayid Sabiq, Fiqhu Sunnah Bairut Libanon:Darul Fikr, Cet kedua, 1998. Juz 3

16 Ibid...Hal 14

17 Ibid 
rekannya. Apabila salah satu dari keduanya berkhianat, aku keluar dari keduannya" 18

Para Ulama Fiqih berbeda pendapat tentang pembagian macammacam Syirkah dalam pembahasan perkongsian (syirkah) yang diperbolehkan dan yang tidak diperbolehkan.

Secara garis besar Fuqaha Mesir (mayoritas bermadzhab Syafi,I dan Maliki), membagi syirkah kepada empat macam yaitu: Syirkah Inan, Syirkah Abdan, Syirkah Mufawwadhah, dan Syirkah Wujuh. ${ }^{19}$

a. Syirkah Inan, yaitu syirkah terbatas dalam bentuk penggabungan harta dan usaha untuk mendapatkan untung. Sedangkan perolehan masingmasing pihak dengan cara lain seperti salah seorang mendapat hibah, hadiah atau lainnya, tidak menjadi syirkah dan tetap menjadi milik masing-masing.

b. Syirkah Abdan, yaitu syirkah dalam bidang pemberian jasa atau melakukan pekerjaan. Jasa atau pekerjaan yang dilakukan itu mungkin jasa atau pekerjaan yang sama mungkin juga jasa atau pekerjaan yang berlainan.

c. Syirkah Mufawwadhah, ialah syirkah yang tidak terbatas dalam penggabungan harta dan usaha untuk mendapatkan untung serta meliputi pula perolehan masing-masing pihak dengan cara lain seperti seseorang mendapatkan hadiah, hibah dan lain-lain.

d. Syirkah Wujuh, adalah syirkah antara dua orang atau lebih dengan hanya bermodalkan kepercayaan.

Sedangkan Ulama Madzhab Hanafi, seperti yang dapat disimpulkan dari kitab "al-Fiqh 'alal Madzhaib al-Arba'ah" jilid III halaman 63-68 membagi syirkah menjadi:

a. Syirkah Milk, ialah syirkah terhadap suatu benda atau kekeayaan dengan tidak ada kesengajaan untuk mengadakan perjanjian khusus terlebih dahulu.

${ }^{18}$ Abu Daud, Sunan Abi Daud, Riyadh:Baitul Afkar Ad-Dauliyyah,1998

${ }^{19}$ Ibn Rusyd al-Qurtubi, Bidayah al-Mujtahid wa Nihayah al-Muqtashid, Mesir: Maktabah Musthofa al-Baaby al-Halby, 1960, juz 2, h...201 
b. Syirkah Uqud, ialah syirkah yang timbulnya karena adanya perjanjian terlebih dahulu antara dua orang atau lebih mengenai suatu usaha. Syyirkah ini dibagi enam macam:

1) Syirkah Mufawwadhah bil Amwal, yaitu perkongsian antara dua orang atau lebih tentang suatu macam perniagaan.

2) Syirkah 'Inan bil Amwal, yaitu perkongsian antara dua orang atau lebih tentang suatu macam perniagaan atau segala macam perniagaan.

3) Syirkah Abdan Mufawwadhah, ialah perkongsian dengan bermodal tenaga yang kemudian ada pembagian yang sama antara keuntungan atau kerugian.

4) Syirkah Abdan Inan, yaitu perkongsian tenaga dengan perbedaan tenaga kerja dan upah.

5) Syirkah Wujuh Mufawwadhah, ialah perkongsian dengan bermodalkan tenaga saja.

6) Syirkah Wujuh Inan, ialah perkongsian kepercayaan tanpa syarat. ${ }^{20}$

Para Ulama sepakat tentang bolehnya Syirkah 'Inan, sedangkan dalam Syirkah Mufawwadhah hanya Madzhab Hanafi dan Maliki yang memperbolehkan sedangkan Madzhab Syafi'i tidak memperbolehkannya. ${ }^{21}$ Begitu juga dalam Syirkah Abdan, menurut Madzhab Syafi'i adalah tidak boleh sedangkan menurut Madzhab Maliki dan Hambali adalah boleh hanya saja Imam Malik mensyaratkan pekerjaan yang mereka lakukan adalah sama sejenis dan satu tempat. Dan dalam Syirkah Wujuh, hukumnya boleh menurut Madzhab Hanafi dan Hambali, sedangkan menurut Syafi'iyah dan Malikiyah adalah tidak boleh.

Alasan Imam Syafi'i tidak memperbolehkan Syirkah Mufawwadhah dikarenakan syirkah ini mengandung bermacam-macam ghurur (penipuan dan ketidaktentuan). Sedangkan alasan ketidakbolehan Syirkah Abdan, menurut Imam Syafi'I karena syirkah (perkongsian) hanya berlaku pada harta bukan pada tenaga. "Adapun Ulama yang memperbolehkan syirkah jenis ini (syirkah abdan) yaitu Malikiyah dan Hanabilah beralasan bahwa tujuan dari

20 Abdurrrahman Al-Jaziri, Al-Fiqhu 'alal Madzahib al-Arba'ah, Mesir: Maktabah atTijariyah al-Kubra, 1969, Jilid III, h. 63-68

${ }^{21}$ Sayyid Sabiq, Fiqhussunah, Bairut Libanon: Darul Fikr, cet ke 2, 1998, Juz 3, h..209 
perkongsian antara lain adalah dalam pembagian Harta Bersama (gono-gini) antara suami-istri ketika terjadi perceraian tidak ada pembagian masingmasing secara pasti (tsabit) misalkan, istri $50 \%$ dan suami $50 \%$. Namun pembagiannya bergantung pada kesepakatan antara suami dan istri berdasarkan musyawarah atas dasar saling ridha. Inilah yang disebut dengan as-Shulhu (perdamaian) antara suami dan istri.

Dalam surat an-Nisa ayat 128 Allah berfirman:

"Dan jika seorang wanita khawatir akan nusyuz atau sikap tidak acuh dari suaminya, maka tidak mengapa bagi keduanya mengadakan perdamaian yang sebenar-benarnya, dan perdamaian itu lebih baik (bagi mereka)...." (anNisa:128) ${ }^{22}$

Dari Amru bin 'Auf Al-Muzni, bahwa Rasulullah Saw bersabda:

"Perdamaian adalah boleh diantara kaum muslimin, kecuali perdamaian yang mengharamkan yang halal dan perdamaian yang menghalalkan yang haram. ${ }^{23}$

Sebagai pengantar dari hadits diatas Syaikh as-Shan'ani dalam kitab Subulussalam mangatakan:

"Para Ulama telah membagi ash-shulhu (perdamaian) menjadi beberapa macam: perdamaian antara muslim dan kafir, perdamaian antara suami dan istri, perdamaian antara kelompok yang adil, perdamaian antara dua orang yang bertahkim kepada hakim (qadhil), perdamaian masalah tindak perlukaan seperti pemberian maaf untuk sanksi harta yang seharusnya diberikan dan perdamaian untuk memberikan sejumlah harta kepada lawan sengketa jika terjadi pada harta milik bersama dan hak-hak. Pembagian inilah yang disebut para fuqoha pada bab untuk medapatkan keuntungan. ${ }^{24}$

Syirkah Abdan boleh dilakukan, baik pekerjaan antara yang berserikat itu sama ataupun berbeda, baik keduanya bekerja atau salah satu dari keduanya saja yang bekerja baik keduanya bekerja sendiri-sendiri maupun bersama-sama, syirkah ini juga dinamakan dengan syirkah a'mal (pekerjaan), abdan (badan), shana'i (kerajinan) atau taqabbul (penerimaan). ${ }^{25}$

${ }^{22}$ Al-Qur'an, Terjemah, h..14

${ }^{23}$ Abi Abdillah Ibn Majah Al-Qozwaini, Sunan Ibnu Majah, Riyadh Darussalam, 1420 H. Hadits ke 2353, h..337

${ }^{24}$ Ibid

${ }^{25}$ Rusyd, Bidayah, h..18 
Dalil dibolehkannya syirkah (persekutuan) ini adalah riwayat Abu Ubaidah bahwa Abdullah Ibn Mas'ud berkata:

"Aku bersekutu dengan 'Ammar dan Sa'ad pada apa yang kami dapatkan dalam perang badar. Sa'ad datang dengan membawa dua orang tawanan, sedangkan aku dan 'Ammar datang tanpa membawa sesuatu pun. ${ }^{26}$

Dari macam-macam syirkah serta adanya perbedaan pendapat di kalangan Ulama dan melihat praktek gono-gini dalam masyarakat Indonesia dapat disimpulkan bahwa harta bersama (gono gini) termasuk dalam syirkah abdan, dikatakan syirkah abdan karena dalam kenyataannya sebagian nesar suami istri dalam masyarakat Indonesia sama-sama bekerja membanting tulang berusaha untuk mendapatkan nafkah hidup keluarga sehari-hari atau jika memang hanya suami yang bekerja sedangkan istri sebagai ibu rumah tangga tetap istri memiliki peranan besar dalam menjaga keutuhan dan kelangsungan keluarga seperti mengurusi urusan rumah tangga, memelihara dan mendidik anak-anak, bahkan berbelanja menyediakan makan dan minum ketika suami bekerja maka dengan hal ini suami telah menerima bantuan yang sangat berharga dan sangat mempengaruhi kelancaran pekerjaannya sehari-hari yang secara tidak langsung mempengaruhi juga pada jumlah harta yang diperoleh.

Pada dasarnya para Ulama tidak menentukan secara pasti tentang pembagian harta (benda) syirkah antara dua orang yang berserikat ketika perserikatan itu bubar, begitu juga dalam syirkah abdan atau as-shulhu. ${ }^{27}$

Dengan demikian berdasarkan dalil diatas jika suami istri bercerai dan hendak membagi harta gono gini maka dapat ditempuh dengan jalan perdamaian (as-shulhu) yaitu pembagian harta gono gini bergantung pada musyawarah dan kesepakatan antara suami istri, boleh jadi suami mendapatkan $50 \%$ dan istri $50 \%$, boleh suami mendapat $30 \%$ dan istri $70 \%$ atau sebaliknya dan boleh juga pembagian dengan nisbah (persentase) yang lain. Semuanya dibenarkan oleh syara' selama merupakan hasil dari perdamaian yang telah ditempuh berdasarkan kerelaan masing-masing.

\footnotetext{
${ }^{26}$ Abi Abdirrahman an-Nasa'I, Sunan an-Nasa'I, Riyadh: Darussalam 1420 H. Hadits ke 470., h..646

${ }^{27}$ Muhammad bin Isma'il as-Shan'ani, Subulussalam, Mesir: Maktabah Musthofa alBaaby al-Haaby, cet 41960 .
} 


\section{Harta Menurut Undang-Undang Perkawinan No.1 Tahun 1974}

Dalam Undang-Undang Perkawinan No.1 Tahun 1974 pasal 1, disebutkan bahwa:

"Perkawinan adalah ikatan lahir batin antara seorang pria dan seorang wanita sebagai suami istri, dengan tujuan untuk membentuk keluarga (rumah tangga) yang bahagia dan kekal, berdasarkan Ketuhanan Yang Maha Esa" 28

Dari pasal tersebut tersimpul adanya asas bahwa antara suami istri terdapat ikatan yang sangat erat, yang meliputi tidak hanya ikatan lahir tetapi meliputi ikatan jiwa, batin atau ikatan rohani, jadi menurut asasnya suami istri bersatu baik dalam segi material maupun dalam segi spiritual.

Mengenai harta benda dalam perkawinan, diatur dalam Pasal 35, 36 dan 37 Undang-Undang Perkawinan No.1 Tahun 1974, yaitu:

\section{Pasal 35}

1) Harta benda yang diperoleh selama perkawinan menjadi harta bersama.

2) Harta bawaan masing-masing suami dan istri dan harta benda yang diperoleh masing-masing sebagai hadiah atau warisan adalah dibawah penguasaan masing-masing sepanjang para pihak tidak menentukan lain.

\section{Pasal 36}

1) Mengenai harta bersama, suami istri dapat bertindak atas persetujuan kedua belah pihak.

2) Mengenai harta bawaan masing-masing, suami dan istri mempunyai hak sepenuhnya untuk melakukan perbuatan hukum mengenai harta bendanya. ${ }^{29}$

Dari pasal-pasal ini dapat disimpulkan bahwa pada dasarnya dalam sebuah keluarga setidaknya terdapat dua jenis harta yaitu:

\section{Harta Pribadi dan harta bawaan}

Yaitu harta yang telah dimiliki oleh suami atau istri sebelum mereka melangsungkan pernikahan dan harta yang diperoleh masing-masing suami istri sebagai hadiah, atau warisan. Mengenai harta ini secara hukum suami atau istri mempunyai otoritas penuh untuk

28 Pasal 1 Undang-Undang Perkawinan No.1 Tahun 1974, Jakarta: PT Tintamas Indonesia, 1986

${ }^{29} \mathrm{Ibid}$, h. 23 
menggunakannya tanpa harus ada persetujuan pihak lain dalam penggunaannya (pasal 36 ayat 2), boleh juga harta bawaan dari masing-masing suami istri digabungkan menjadi harta bersama atau harta perkawinan (pasal 35 ayat 2).

\section{Harta bersama atau harta gono gini}

Yaitu harta yang diperoleh suami istri sepanjang keduanya terikat oleh perkawinan, baik yang mengusahakan harta tersebut hanya suami saja, istri saja atau diusahakan oleh keduanya. Karena dalam ketentuan diatas tidak menyebutkan dari mana dan dari siapa harta tersebut berasal. Dalam penggunaan harta bersama ini harus ada persetujuan antara kedua belah pihak suami dan istri. Selanjutnya dalam pasal 37 di sebutkan bahwa: "Bila Perkawinan Putus karena perceraian, harta bersama diatur menurut hukumnya masing-masing"30 yang dimaksud dengan "hukumnya masing-masing" adalah Hukum Agama, hukum adat atau hukum-hukum yang lain. ${ }^{31}$

Jika sebuah perkawinan putus karena perceraian (bukan karena kematian) maka menurut pasal diatas harta bersama diatur menurut agama yang dianut oleh suami istri yang bersangkutan atau di atur menurut hukum adat yang berlaku dalam masyarakat tersebut.

\section{Harta Bersama Menurut Kompilasi Hukum Islam}

Dalam Undang-undang Nomor 1 Tahun 1974 masalah harta bersama hanya diatur secara singkat dan umum dalam Bab VII dan hanya terdiri dari 3 pasal (pasal 35, 36 dan 37). Sedangkan dalam Kompilasi Hukum Islam di atur lebih jelas dan rinci yaitu dalam Bab XIII Pasal 85, 86, 87, 88, 89, 90, 91, 92, 93, 94, 95, 96 dan 97 tentang Harta Kekayaan dalam Perkawinan.

Pada Pasal 85 dijelaskan bahwa "Adanya harta bersama dalam perkawinan itu tidak menutup kemungkinan adanya harta milik masingmasing suami atau istri. Pasal 86 (1) menyatakan bahwa pada dasarnya tidak ada percampuran antara harta suami dan harta istri karena perkawinan, sementara pasal 86 (2) mengatur bahwa harta istri tetap menjadi hak istri dan

\footnotetext{
${ }^{30}$ Ibid.

31 “Penjelasan atas Undang-Undang Republik Indonesia Nomor 1 Tahun 1974 Tentang Perkawinan," dalam Hazairin, Tinjauan Mengenai U.U Perkawinan Nomor: 1-1974, Jakarta: Tintamas, 1986
} 
dikuasai sepenuhnya olehnya, demikian juga harta suami tetap menjadi hak suami dan dikuasai sepenuhnya olehnya. Pasal 87 (1) mengatur bahwa harta bawaan dari masing-masing suami atau istri dan harta yang diperoleh masing-masing sebagai hadiah atau warisan adalah dibawah penguasaan masing-masing sepanjang para pihak tidak menentukan lain dalam perjanjian perkawinan.

Sedangkan pasal 87 (2) menyatakan bahwa suami dan istri mempunyai hak sepenuhnya untuk melakukan perbuatan hukum atas harta masing-masing berupa hibah, hadiah, sodaqoh atau lainnya. Pasal 88 menjelaskan bahwa apabila terjadi perselisihan antara suami istri tentang harta bersama, maka penyelesaian perselisihan itu diajukan kepada Pengadilan Agama. Pasal 89 menyatakan bahwa suami bertanggung jawab menjaga harta bersama, harta istri maupun hartanya sendiri, sementara Pasal 90 menyatakan bahwa istri turut bertaggung jawab menjaga herta bersama, maupun harta suami yang ada padanya.

Pasal 91 terdiri dari empat ayat: (1) harta bersama sebagaimana tersebut dalam pasal 85 di atas dapat berupa benda berwujud atau benda tidak berwujud, (2) harta bersama yang berwujud dapat meliputi benda tidak bergerak, benda bergerak dan surat-surat berharga, (3) harta bersama yang tidak berwujud dapat berupa hak dan kewajiban, dan (4) harta bersama dapat dijadikan sebagai barang jaminan oleh salah satu pihak atas penunjukan pihak lain. Pasal 92 menyatakan bahwa suami istri tanpa persetujuan pihak lain tidak di perbolehkan menjual atau memindahkan harta bersama.

Pasal 93 terdiri dari 4 ayat: (1) pertanggung jawaban hutang suami atau istri dibebankan kepada hartanya masing-masing; pertanggungjawaban terhadap hutang yang dilakukan untuk kepentingan keluarga, dibebankan kepada harta bersama, (3) bila harta bersama tidak mencukupi, dibebankan kepada harta suami, (4) bila harta suami tidak ada atau tidak mencukupi maka dibebankan kepada harta istri.

Pasal 94 terdiri ari 2 ayat: (1) harta bersama perkawinan seorang suami yang mempunyai istri lebih dari seorang masing-masing terpisah dan berdiri sendiri; (2) pemilikan harta bersama dari perkawinan seorang suami yang mempunyai istri lebih dari seorang sebagaimana tersebut dalam ayat (1), dihitung pada saat berlangsungnya akad perkawinan yang kedua, ketiga atau yang keempat. 
Pasal 95 terdiri dari 2 ayat: (1) dengan tidak mengurangi ketentuan pasal 24 ayat 2 huruf c Peraturan Pemerintah No. 9 Tahun 1975 dan Pasal 136 ayat (2), suami atau sitri dapat meminta Pengadilan Agama untuk meletakkan sita jaminan atas harta bersama tanpa adanya permohonan gugatan cerai, apabila salah satu melakukan perbuatan yang merugikan dan membahayakan harta bersama seperti judi, mabuk, boros dan sebagainya. (2) selama masa sita dapat dilakukan penjualan atas harta bersama untuk kepentingan keluarga dengan izin Pengadilan Agama.

Pasal 96 terdiri dari 2 ayat: (1) apabila terjadi cerai mati, maka separoh harta bersama menjadi hak pasangan yang hidup lebih lama; (2) pembagian harta bersama bagi seorang suami atau istri yang istri atau suaminya hilang harus di tangguhkan sampai adanya kepastian matinya yang hakiki atau matinya secara hukum atas dasar putusan Pengadilan Agama. Dan terakhir, Pasal 97 mengatur bahwa janda atau duda cerai hidup masing-masing berhak seperdua dari harta bersama sepanjang tidak ditentukan lain dalam perjanjian perkawinan.

Secara singkat pokok-pokok hukum harta bersama dalam Bab XIII Kompilasi Hukum Islam ini dapat diuraikan sebagai berikut:

a. Harta bersama dipisah dari harta pribadi masing-masing:

1) Harta pribadi tetap menjadi milik pribadi dan dikuasai sepenuhnya oleh pemiliknya (suami atau istri)

2) Harta bersama menjadi hak bersama suami istri dan terpisah sepenuhnya dari harta pribadi.

b. Harta bersama terwujud sejak tanggal perkawinan dilangsungkan:

1) Sejak itu dengan sendirinya terbentuk harta bersama.

2) Tanpa mempersoalkan siapa yang mencari.

3) Tanpa mempersoalkan atas nama siapa terdaftar.

c. Tanpa persetujuan bersama, suami atau istri tidak boleh mengasingkan atau memindahkan.

d. Hutang untuk kepenntingan bersama dibebankan kepada harta bersama.

e. Dalam perkawinan serial atau poligami wujud harta bersama terpisah antara suami dengan masing-masing istri. 
f. Apabila perkawinan putus (mati atau cerai):

1) Harta bersama dibagi dua;

2) Masing-masin mendapat setengah bagian;

3) Apabila terjadi kematian, bagiannya menjadi tirkah.

\section{Penutup}

Pada dasarnya dalam hukum Islam tidak disebutkan secara spesifik tentang istilah harta bersama (gono-gini) dalam keluarga, namun kemudian para pakar hukum Islam di Indonesia menganalogikan harta bersama kepada syirkah. Jika terjadi sengketa dalam pembagian harta bersama hukum Islam menawarkan solusi As-shulhu (perdamaian) dan musyawarah kekeluargaan untuk mencari jalan keluar yang saling menguntungkan dan penuh keridhaan, sedangkan dalam perundang-undangan yang berlaku di Indonesia, harta bersama dibagi dua antara suami dan istri pasca perceraian.

\section{Pustaka Acuan}

Departemen Agama Republik Indonesia, Al-Qur'an dan Terjemahnya, Bandung: PT Syamil Cipta Media, 2005.

Departemen Pendidikan dan Kebudayaan, Kamus Besar Bahasa Indonesia, Jakarta: Balai Pustaka, 1991.

Ensiklopedia Hukum Islam, Jakarta: PT Ichtiar Baru van Hoeve, 2001.

R.Van Dijk, Pengantar Hukum Adat Indonesia, terj. A. Soehardi, Jakarta: Penerbit Sumur Bandung, 1980.

R. Wirjono Prodjodikoro, Hukum Perkawinan di Indonesia, Jakarta: Sumur Badung, 1960.

Muhamad Isna Wahyudi, "Harta Bersama: Antara Konsepsi dan Tuntutan Keadilan". 
M. Yahya Harahap, "Informasi Materi Kompilasi Hukum Islam: Mempositifkan Abstraksi Hukum Islam" dalam Cik Hasan Bisri, Ed.,Kompilasi Hukum Islam dan Peradilan Agama dalam Sistem Hukum Nasional, Jakarta: Logos Wacana Ilmu, 1999.

Sayyid Sabiq, Fiqhussunah, Bairut Libanon: Darul Fikr, cet ke 2, 1998, Juz 3.

Abu Dawud, Sunah Abi Dawud, Riyadh: Baitul Afkar ad-Dauliyyah, 1998.

Ibn Rusyd al-Qurtubi, Bidayah al-Mujtahid wa Nihayah al-Muqtashid, Mesir: Maktabah Musthofa al-Baaby al-Haaby, 1960, juz 2.

Abdurrahman Al-Jaziri, Al Fighu 'alal Madzahib al-Arba'ah, Mesir: Maktabah atTijariyah al-Kubra, 1969, Jilid III.

Abi Abdirrahman an-Nasa'I, Sunan an-Nasa'I, Riyadh: Darussalam 1420 H. Hadits ke 470 .

Abi Abdillah Ibn Majah Al-Qozwaini, Sunan Ibnu Majah, Riyadh: Darussalam, 1420 H. Hadits ke 2353.

Muhamad bin Isma'il as-Shan'ani, Subulussalam, Mesir: Maktabah Musthofa al-Baaby al-Halby, cet 4. 1960 .

Undang-Undang Perkawinan No. 1 Tahun 1974, Jakarta: PT Tintamas Indonesia, 1986.

Penjelasan atas Undang-Undang Republik Indonesia Nomor 1 Tahun 1974 Tentang Perkawinan," dalam Hazairin, Tinjauan Mengenai U.U. Perkawinan nomor: 1-1974, Jakarta: Tintamas, 1986. 